\title{
Agrobiodiversity documentation in Puranchaur, Pokhara through four cell analysis: biodiversity of rice
}

\author{
Amrita Paudel*, Anish Paudel, Sushil Shrestha \\ Agriculture and Forestry University, Faculty of Agriculture, Rampur, Chitwan, Nepal \\ ORCID \\ Amrita Paudel https://orcid.org/0000-0003-0322-7262 \\ Anish Paudel https://orcid.org/0000-0002-1364-4054 \\ Sushil Shrestha https://orcid.org/0000-0002-3758-4674
}

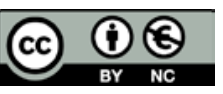

Article Details:

Received: 2021-10-01

Accepted: 2021-11-19

Available online: 2021-11-30

DOI: https://doi.org/10.15414/ainhlq.2021.0032

\begin{abstract}
Agrobiodiversity indicates variety and variability among living organisms present in the farming area. The climatic variability of Nepal has supported the maximum diversity of agricultural crops and animal species. The number of cultivated food crops in Nepal is 577 including forage/pasture species among which 484 are indigenous and 93 are introduced/exotic species. This study was carried out to assess the biodiversity of rice in Puranchaur, Pokhara, Nepal. A field survey was conducted from 60 farmers who represent the total farming population. The collected data from the questionnaire survey were further analysed using SPSS Statistics 23.0. Out of the average total land ( 0.50 hectares), the average total cultivated land was only 0.39 hectares. The average productivity of rice in the study area was $4.035 \mathrm{~m} / \mathrm{ha}$. The different rice varieties cultivated by farmers in the study area were documented and analysed through four cell analysis method since it is a popular analysis tool to manage the local level agricultural diversity. From the study three rice landraces Pahele, Gurdi, and Jhinuwa were found to be the most preferred, and Anadi is the least preferred in the area. Based on this study, possible conservation strategies for threatened and endangered species were also identified. The possible interventions include on-farm conservation, in situ conservation, ex situ conservation, and conservation plant breeding.
\end{abstract}

Keywords: rice, diversity, landraces, four-cell analysis

\section{Introduction}

Agrobiodiversity is the combination of environment, biological diversity, and monitoring systems employed by a varying group of people and thereby exploitation of water and land resources to maintain the architecture of agro-ecosystem for food security and agricultural production (FAO, 1999). Nepal's geographical variety is immense, ranging from tropical flatlands on the southern side to the rocky, delicate, and snow-covered Himalayas on the northern side (MOFSC, 2014).
Moving from the terai to the mountainous area of Nepal revealed a total of 118 ecosystems. A broad range of climate and topography has benefitted agricultural methods, their wild counterparts, and biological types (Khanal and Dangol, 2016). Nepal ranks tenth in Asia and thirty-first worldwide in terms of flowering plant diversity. There are 790 plant species important from the nutritional point of view and 577 cultivated plant species, including pasture species. There are 484 indigenous species and 93 exotic species among the

\footnotetext{
*Corresponding Author: Amrita Paudel, Agriculture and Forestry University, Rampur Chitwan Nepal $\triangle$ pdlamr1998@gmail.com
} 
577 species (Joshi et al., 2017). In order to conserve biodiversity along with agricultural biodiversity, Nepal joined the CBD (Convention on Biological Diversity) and ITPGRFA (International Treaty on Plant Genetic Resources for Food and Agriculture) in 1992 and 2009, respectively, Protocol of Cartagena on Biosafety and the Nagoya in 2001 and 2019, respectively; possess Agrobiodiversity Policy-2007 (updated on 2014) and various seed related acts, visions and policies (Joshi et al., 2020).

Cereals are the most pivotal food crops, accounting for 49.41 percent of the country's GDP. Rice is the dominant cereal grain, accounting for 20.75 percent of total AGDP (Bista et al., 2013). Rice production in Nepal lifted from 2.3 million tons to 5.61 million tons (1970-2019), climbing at a yearly pace of $2.78 \%$ (World Data Atlas, 2019). Rice production has grown at an average annual rate of $0.16 \%$ over the past 50 years, which is more or less than the level of the growing population. Traditional agricultural techniques, shortage of experienced labour force, environmental degradation, and other obstacles contribute to the yield gap of 45 to $55 \%$ in rice (IRRI, n.d.). So, to improve crop productivity, the genetic resources must be conserved since they facilitate to development high yielding breeding lines and qualitative cultivars.

Nepal is one of the important centres for rice genetic resources as more than 1700 rice genetic resources have been identified, ranging in altitude from 60 to 3,050 meters (MoAD, 2015). The ecological condition of terai, mid-hills, and high hills distinguish the prevalence of landraces of rice (Bajracharya et al., 2010)in traditional rice farming systems many diverse landraces are grown in all of the rice agro-ecosystems from low to high altitude. Three case study sites were selected to represent the major rice agro-ecozones: Bara (100-150 m found that high hills have the lowest rice diversity due to the chilling temperature and are dominated by the cold-tolerant Marshi rice while mid-hills have the highest rice diversity due to varying agroecosystems with a wide range of environmental variability. Similarly, terai (grain store of the country) has low diversity due to the landraces being phased out in favour of new varieties, but not due to ecology.

Diverse genetic resources are the foundation for sustainable development in agriculture. The availability of agricultural genetic resources is the fundamental requirement for achieving a further increase in productivity and maintaining food security in the country. However, genetic erosion is increasingly becoming the main issue in the most of the crop species around the world. Among the various methods used in agrobiodiversity documentation within the farming community, four-cell analysis is one of the most suitable and rapid methods for determining the amount and distribution of crop diversity within agricultural communities. It considers the richness and evenness of inter-specific and intra-specific biodiversity (Sthapit et al., 2014).

\section{Material and methodology}

\section{Broad objective}

The main objective of the study was to assess the diversity in the rice landraces being grown in the study area.

Specific objectives of the study:

- Record-keeping the rice landraces being grown in the study area.

- Analysis of the varietal selection and potential conservation approaches.

\section{Site selection}

For the documentation of agrobiodiversity, an assessment of rice landraces that are being grown in Puranchaur, Pokhara was done. Puranchaur is a small village at a distance of $17 \mathrm{~km}$ from Pokhara city. Puranchaur is situated at an altitude of $940 \mathrm{~m}$. a. s. l. with a mean annual temperature of 20.6. It falls at a latitude of 28.32 degrees north and a longitude of 83.99 degrees east (Wikipedia, 2020).

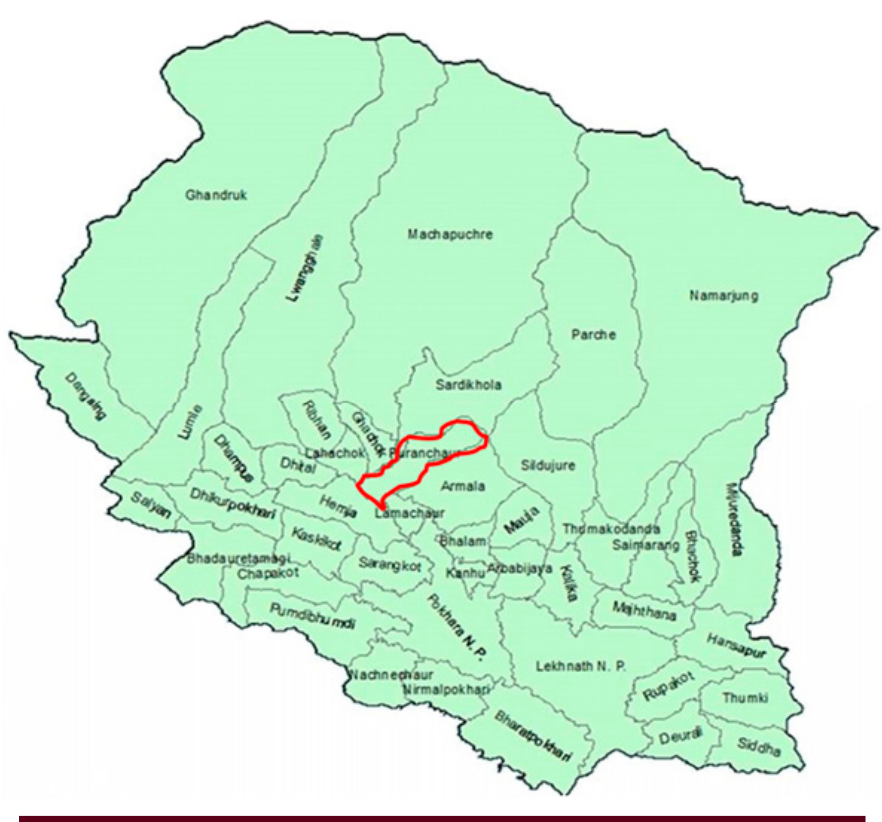

Figure 1 Map of Kaski district, Nepal showing Puranchaur village (NEKSAP, 2013) 


\section{Method of data collection}

The questionnaire was designed to collect data from the farmers. The pre-tested questionnaire was presented for direct interaction with a group of local farmers in the form of a field survey. Altogether 60 farmers were asked a series of questions as a representative of the total farming population in this area.

\section{Four cell analysis}

For four-cell analysis, rice varieties that are being cultivated by the farmers in the study area were documented and were classified into four different groups. The four groups were arranged based on the area (large and small) and household (many and few) as shown in the figure below. Then the discussion was carried out on the reasons the farmers have preferred some varieties over others. Based on the discussion with the farmers' methods for conservation of those varieties that are in threat and endangered were also identified. Generally, for this purpose, we prefer focus group discussion.

\section{Statistical analysis}

The data were collected, classified, and analyzed using various statistical procedures. The collected data were analyzed using SPSS Statistics 23.0 through descriptive statistics. Various bar diagrams and charts are used for the interpretation of the analyzed data.

\section{Result and discussion}

Rice which is among the three major leading crops in the world; together with wheat and mays they supply more than $50 \%$ of all calories consumed by the entire population of the world (FAO, 2001).

According to FAOSTAT, in 2018-2019 rice was planted in 118 countries on an area of 167 million hectares, the annual grain production in the world is about 782 million tons. The main rice producers in the world are China (over 214 million tons), India (over 172 million tons), Indonesia (83 million tons), Bangladesh (56 million tons), Vietnam (44 million tons), Thailand (32 million tons) and Myanmar (25 million tons) (FAOSTAT, 2018-19).

Rice is majorly grown in Asian, African and Latin American countries, it is the chief and cheapest source of carbohydrate in majority of the developing nations. There has been a rise in global consumption of rice with subject to global population growth, raising the need to increase production with improvement in technology (Färe et al., 1994, 2001; Hassen et al., 2017; Bagirov et al., 2020).

\section{Demographic information}

The demography includes informations about age, gender, ethnicity, educational status, economically active population, main occupation, type of family of the respondents, food sufficiency (months), land distribution, and amount of cereal production in quintals.

\section{Age of respondents}

During the field survey, the majority of the respondents (38.3\%) were 35 to 45 years old while only $6.7 \%$ of respondents were 25 to 35 years old (Table 1 ).

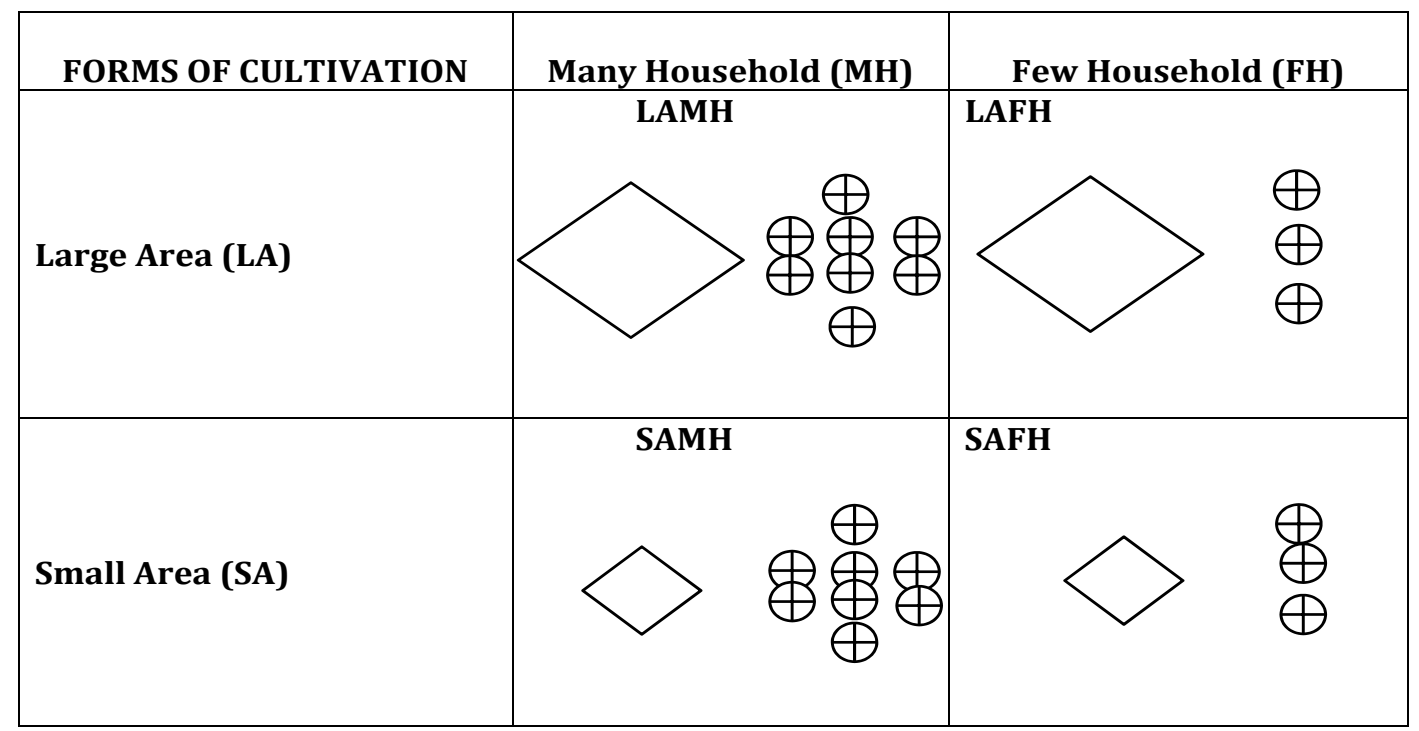

Figure 2 Four cell analysis showing the various forms of cultivation at a certain area and household (Shrestha et al., 2015) 
Table 1 Age of the respondents

\begin{tabular}{lcc}
\hline Age group & Frequency & Percent \\
\hline $\mathbf{2 5 - 3 5}$ & 4 & 6.7 \\
$\mathbf{3 5 - 4 5}$ & 23 & 38.3 \\
$\mathbf{4 5 - 5 5}$ & 18 & 30.0 \\
$\mathbf{5 5 - 6 5}$ & 10 & 16.7 \\
$\mathbf{6 5}$ and above & 5 & 8.3 \\
Total & 60 & 100.0 \\
\hline
\end{tabular}

\section{Gender of respondents}

Out of 60 respondents, the male respondents were $68.3 \%$ and female respondents were $31.7 \%$; being selected for the survey (Figure 3).

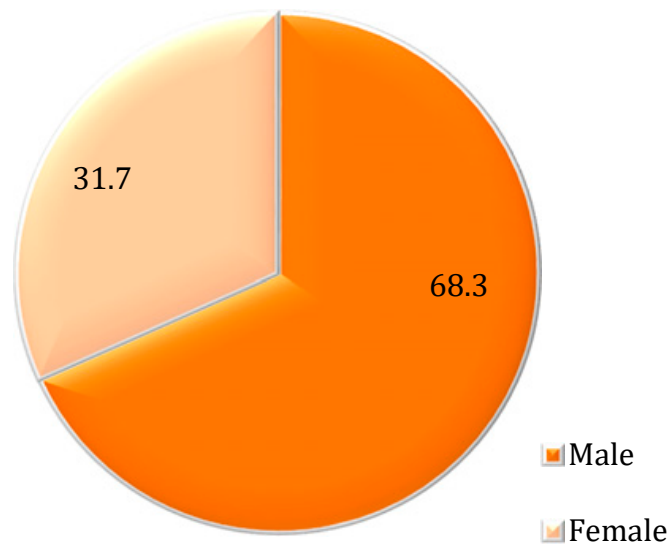

Figure 3 Gender of the respondents (\%)
Table 2 Education of the respondents

\begin{tabular}{lcc}
\hline Age group & Frequency & Percent \\
\hline Illiterate & 3 & 5 \\
Literate & 15 & 25 \\
School Leaving Certificate & 18 & 30 \\
Intermediate/+2 & 15 & 25 \\
Bachelors and above & 9 & 15 \\
Total & 60 & 100.0 \\
\hline
\end{tabular}

Table 3 Economically active population

\begin{tabular}{lcc}
\hline Age group & Frequency & Percent \\
\hline Below 15 & 71 & 23.13 \\
$\mathbf{1 5}$ to 59 & 201 & 65.47 \\
Above 59 & 35 & 11.40 \\
Total & 307 & 100.0 \\
\hline
\end{tabular}

\section{Ethnicity of respondents}

From the survey, the majority of the respondents were Brahmins (66.7 \%), followed by Chhetris (28.3 \%) and a few were Dalits (5\%) (Figure 4). This shows that the area is largely covered by the Brahmin community.

\section{Education of respondents}

Table 2 below shows that $30 \%$ of the respondents had an School Leaving Certificate (SLC level of education in Nepal), $25 \%$ were literate which means they can read and write, $25 \%$ had intermediate/+2 level degree, $15 \%$ respondents had bachelors and above degrees while only $5 \%$ were illiterate.

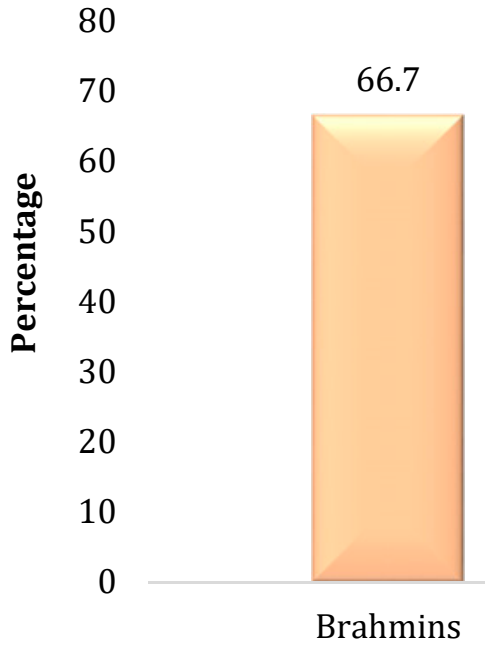

28.3

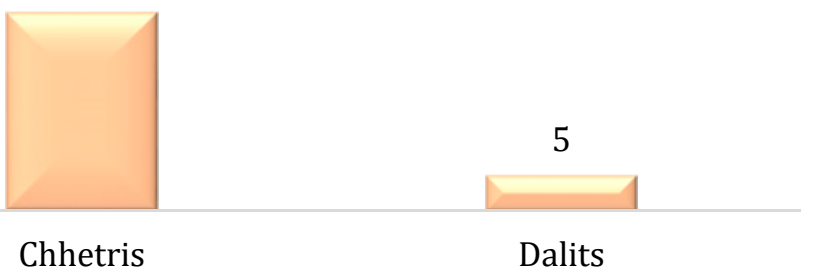

Figure 4 Ethnicity of the respondents 


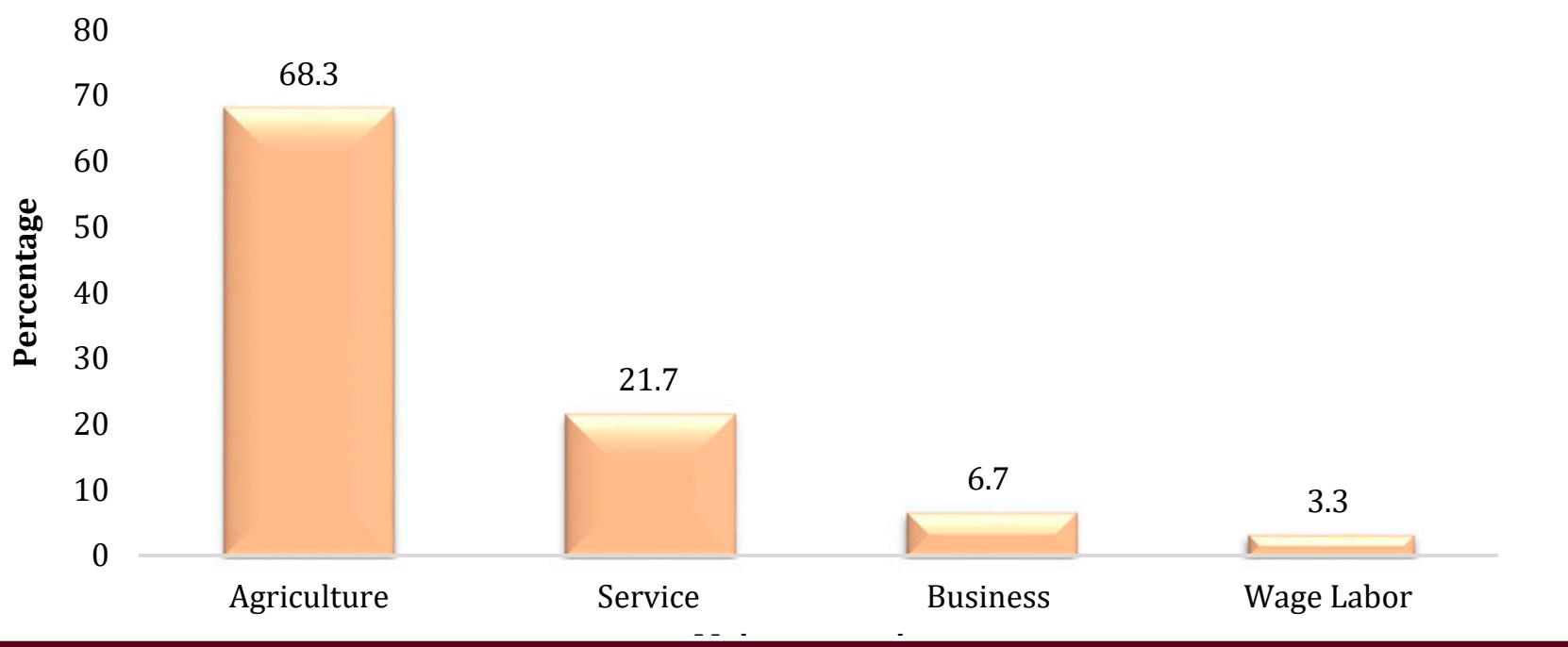

Figure 5 Main occupation of the respondents

\section{Economically active population}

There was a majority of economically active population aged 15 to 59 years old accounting $65.47 \%$ followed by $23.13 \%$ respondents below 15 years old and the respondents above 59 were the lowest with $11.40 \%$ (Table 3).

\section{Main occupation of respondents}

The majority of the respondents were found to be engaged in agriculture (68.3\%) followed by $21.7 \%$ on service, $6.7 \%$ on business, and $3.3 \%$ as wage labour (Figure 5).

\section{Type of the family of respondents}

Figure 6 below shows that the majority of the respondents have a joint type of family (61.7\%) while $38.3 \%$ of the respondents have a nuclear family type. Join type family means a group in which

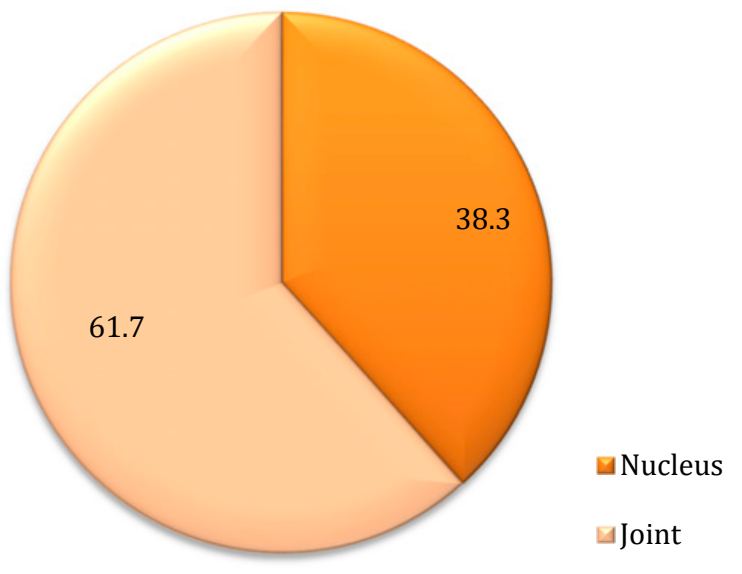

Figure 6 Type of family of the respondents descent through either the female or the male line is emphasized, live together with their spouses and offspring in one homestead and under the authority of one of the members and nuclear family consists of two parents and their children, but not including aunts, uncles, grandparents, etc.

\section{Food sufficiency from own production}

The amount of food produced was sufficient for 6 to 12 months among $45 \%$ of respondents followed by $43.3 \%$ respondents for more than 12 months and only $11.7 \%$ respondents for 3 to 6 months (Table 4).

Table 4 Food sufficiency from own production

\begin{tabular}{lcc}
\hline Age group & Frequency & Percent \\
\hline 3-6 months & 7 & 11.7 \\
6-12 months & 27 & 45.0 \\
>12 Months & 26 & 43.3 \\
Total & 60 & 100.0 \\
\hline
\end{tabular}

\section{Land distribution}

Among the 60 surveyed respondents, the average total land was found to be 0.50 hectares (S.D. $=5.32$ ). Out of total land, the average total cultivated land was only 0.39 hectares (Table 5).

Table 5 Land distribution

\begin{tabular}{lcccc}
\hline $\begin{array}{l}\text { Land (in } \\
\text { hectares) }\end{array}$ & Minimum & Maximum & Mean & $\begin{array}{c}\text { Std. } \\
\text { deviation }\end{array}$ \\
\hline $\begin{array}{l}\text { Total land } \\
\begin{array}{l}\text { Total } \\
\text { cultivated } \\
\text { land }\end{array}\end{array}$ & 0.10 & 1.12 & 0.50 & 5.32 \\
\hline
\end{tabular}




\section{Productivity of rice in metric tons per hectare}

Among the major cereals grown at Puranchaur, there is high production of rice in the study area. The average productivity of rice was $4.035 \mathrm{~m} / \mathrm{ha}$ which is higher than the national productivity $(3.81 \mathrm{~m} / \mathrm{ha})$ (MOALD, 2021).

India is the second largest producer of rice in the world after China, as the country produces 175.58 million tonnes of rice annually (FAOSTAT, 2018). Dey et al. (2020) studied variables area, production and productivity of rice during the period from 1950-1951 to 2015-2016. The total area under rice cultivation in India grew from 30810 thousand hectares in 1950-1951 to 43499 thousand hectares in 2015-2016. There has been not much increase in the area under rice cultivation in India. The growth trend shows that the area under rice grew at a compound growth rate of $0.52 \%$. The rice production of the country increased from 20576 thousand tonnes in 1950-1951 to 104408 thousand tonnes in 2015-2016. The production under rice grew at a compound growth rate of $2.5 \%$. Authors recorded also instability in rice area, production and productivity. During the entire period, highest variation was noticed for production in comparison to area and yield. The variation in rice production was $43.8 \%$, while the variation in area and yield were $11 \%$ and $35.3 \%$, respectively.

In the Russian Federation, there has been an increase in sown areas, productivity and gross harvests. In 2019 , the sown area of rice in Russia was brought to 173.8 thousand hectares, the yield was $5.5 \mathrm{t} / \mathrm{ha}$ and the gross harvest of paddy rice was 1098.7 thousand tons (Bagirov et al., 2020).

In Europe, where Japonica rice is cultivated, Italy is the leading rice producer, with around 227300 ha of ricecultivated areas (Maclean et al., 2002). Additionally, a trend of continuous increase of the rice cultivation surface was observed during the last 30 years; also the area per farm has increased, moving from 20.9 ha of rice per farm in 1983 to 53 ha in 2012, with an increase of 3 to $5 \%$ per year (Hassen et al., 2017).

\section{Agrobiodiversity documentation of rice}

List of rice varieties that are being cultivated in the study area:

- Pahele.

- Gurdi.

- Jethobudho.

- Jhinuwa.

- Dhitale Pahele.

Hybrid.

- Anadi.

Farmers used to grow Sabitri, Gauri, Marsi, and Naule landraces of rice until a few years ago but currently, no farmer in the area is growing these landraces (Rijal et al., 1998) reported that Marsi is under threat and grown under stressful environmental conditions even at Seti river valley. Similarly, research at different ecological zones by Ghimire et al. (2018) found that Marsi is still grown in a limited area among limited households. But in the case of Puranchaur, Marsi is no longer grown in the area.

Flooded rice cultivation can provide important ecosystem services such as the preservation of wetland habitats for a range of aquatic and semi-aquatic wildlife, or of the local traditional landscapes (Hassen et al., 2017).

\section{Four cell analysis}

In four-cell analysis varieties cultivated in many households and large areas denote common varieties, those cultivated in few households and large areas and many households and small areas denote endangered varieties, and those cultivated in few households and small areas denote varieties in threat.

Based on the information collected, landraces Pahele, Gurdi, and Jhinuwa are preferred by most households. Landraces Gurdi and Pahele give high production, so they are the most preferred among the farmers in this area. On selling, Pahele fetches high prices than Gurdi. Jhinuwa variety is also preferred by many farmers as it gives satisfactory production and fetches a higher price on selling than those landraces Gurdi

Table 6 Result of four cell analysis done for rice in Puranchaur, Pokhara

\begin{tabular}{lcc}
\hline Form of cultivation & Many household & Few household \\
\hline \multirow{2}{*}{ Large Area } & 1. Pahele & 1. Jethobudho \\
& 2. Gurdi & 2. Dhitale pahele \\
Small Area & 3. Jhinuwa & 1. Anadi \\
\hline
\end{tabular}


and Pahele, because it is superior in terms of taste. But studies at Seti river valley found that Jhinuwa was under threat (Rijal et al., 1998). They cultivate these three landraces for home consumption, as well as for selling.

Jethobudho and Dhitale Pahele are cultivated by few farmers, and are less preferred landraces. According to the information given by the farmers, Jethobudho matures late in the season, so they do not prefer this landrace, and in the case of Dhitale Pahele, it does not give satisfactory production in this area. Hybrid rice is also a less preferred landrace because of its inferior taste when compared to other local varieties that are being cultivated in the study area.

Anadi is the least preferred landrace in the area. Only a few farmers cultivate in a very small area for home consumption only. Many farmers believe that it is the rice landrace with medicinal importance and superior taste, but they do not cultivate it on a commercial scale due to the very low production potential of this landrace.

But one of the studies by Rijal et al. (1998) at Seti river valley found that Jethobudho, Gurdi, Anadi, and Pahele are mostly grown by farmers; a different case than Puranchaur. Since the landraces Gurdi and Jethobudho were grown in a large area (Table 6), a similar type of wider adaptability was found at Seti river valley (Rijal et al., 1998).

Sawaneh et al. (2013) studied rice productivity of five countries in Southeast Asia for a period of three decades 1980-2010. From the result of the entire period, productivity increased on the average for Myanmar (2.5 \%), Philippines (1.1 \%), Thailand $(1.1 \%)$ and Vietnam (2.5\%) while Malaysia posted a regression in performance with $-0.1 \%$. Countries that sustained total factor productivity growth through technical change include Myanmar, Philippines and Vietnam with technical progress of $2.5 \%, 0.6 \%$ and $1.7 \%$, respectively. Though, Thailand being a major rice exporter in the world has sustained its growth through efficiency improvement $(0.7 \%)$ rather than technical progress $(0.4 \%)$ while Malaysia has shown technical regression $(-0.1 \%)$ over the entire time period. The results show that the average performance (growth) of the countries was sustained mainly by technical change rather than improvement in efficiency change, which is explained according to total factor productivity described by many authors (Caves et al., 1982; Färe, et al., 1994; Fulginiti and Perrin, 1998; Färe, et al., 2001; Pfeiffer, 2003; Coelli et al., 2005).
Research in Philippines analysed the rice production and consumption trends during 15 years (2000-2015) and found variety of factors (vulnerability of rice farming to weather and climate changes and natural disasters; harvest and postharvest techniques; limited rice production area; increasing population; smuggling, etc.) (Exconde, 2016).

\section{Conservation strategy}

The landraces that are the most preferred are common and on-farm conservation can be done easily. But the less preferred varieties are endangered and at threat of extinction from the region and therefore specific strategies are needed for their conservation. Local Initiatives for Biodiversity, Research and Development (LI-BIRD) has been actively participating in the conservation of local landraces using various biodiversity management community level practices and fairs, seed banks, and participatory plant breeding (Shrestha, 2007). But under our case, conservation strategies for the rice varieties in different categories are as follows:

1. For endangered landraces:

- value addition and product diversification,

- proper market channel,

- varietal improvement through plant breeding tools,

- improved market facilities,

- in situ conservation,

- launching germplasm conservation practices,

- exchange of seed through farmer seed network system.

2. For the varieties in threat:

- ex situ conservation,

- collection and preservation of germplasm,

- household gene bank improvements,

- establishment of the seed bank and gene bank at the community level.

\section{Conclusion}

Nepal can be considered a biodiversity hotspot being highly diverse in biodiversity under human threat. Nepal is home to a wide range of plant and animal species. Being an agricultural country people grow different landraces of crops and different breeds of animal livestock. Though there exists variation in the use of the plant and animal species, use is not the same for all species. In the case of food crops, the varieties that are least preferred are more vulnerable to extinction. Common varieties can be the best 
conserved on-farm whereas, for endangered and threatened ones conservation is more difficult. Thus, four-cell analysis can be the best method that helps in the documentation of agrobiodiversity and analysis of possible conservation strategies for different crops. Conservation strategies include on-farm conservation of common and more preferred varieties; value addition, strong market channel, and linkage, diversification, landraces enhancement through selection for endangered cultivars, and ex situ conservation through seed banks, gene banks, etc. for threatened species. Limited access to agricultural genetic resources can lead to food insecurity. Therefore, all relevant stakeholders should join hands and work together for biodiversity conservation through on-farm, ex situ, in situ, and conservation plant breeding.

\section{Conflicts of interest}

The authors declare no conflict of interest.

\section{Ethical statement}

This article does not contain any studies that would require an ethical statement.

\section{References}

Bagirov, V., Treshkin, S., Korobka, A., Dereka, F., Garkusha, S., Kovalev, V., Esaulova, L., \& Kizinek, S. 2020. Scientific support of the rice growing industry of the agroindustrial complex of the Russian Federation in solving the problems of food security. In E3S Web of Conferences 210, 05006 (2020), ITSE-2020.

https://doi.org/10.1051/e3sconf/202021005006

Bajracharya, J., Rana, R. B., Gauchan, D., Sthapit, B.R., Jarvis, D.I., \& Witcombe, J.R. (2010). Rice landrace diversity in Nepal. Socio-economic and ecological factors determining rice landrace diversity in three agroecozones of Nepal based on farm surveys. Genetic Resources Crop Evolution, 57(7), 1013-1022.

Bista, D.R., Amgain, L.P., \& Shrestha, S. (2013). Food security scenario, challenges, and agronomic research directions of Nepal. Agronomy Journal of Nepal, 3, 42-52.

Caves, D.W., Christensen, L.R., \& Diewert, W.E. (1982). The economic theory of index numbers and the measurement of input, output, and productivity. Econometrica: Journal of the Econometric Society, 1393-1414.

Coelli, T. J., \& Rao, D. S. (2005). Total factor productivity growth in agriculture: a Malmquist index analysis of 93 countries, 1980-2000. Agricultural Economics, 32(1), 115-134.

Dey, A., Dinesh, \& Rashmi. (2020). Rice and wheat production in India: An overtime study on growth and instability. Journal of Pharmacognosy and Phytochemistry, 9(2), 158-161.
FAO. (1999). What is Agrobiodiversity? http://www.fao.org/3/y5609e/y5609e01.htm

Exconde, B.A. (2016). Rice production and consumption trends in the Philippines from 2000 to 2015. Yuchengo Center: De La Salle University.

FAOSTAT. World Wheat. Corn and Rice. Oklahoma State University. Available online: http://www.nue. okstate. edu/Crop Information/World Wheat Production.htm (accessed on 8 July, 2019).

Färe, R., Grosskopf, S., \& Lee, W. F. (2001). Productivity and technical change: the case of Taiwan. Applied Economics, 33(15), 1911-1925.

Färe, R., Grosskopf, S., Norris, M., \& Zhang, Z. (1994). Productivity growth, technical progress, and efficiency change in industrialized countries. The American Economic Review, 66-83.

Fulginiti, L. E., \& Perrin, R. K. (1998). Agricultural productivity in developing countries. Agricultural Economics, 19, 45-51.

Ghimire, Y. N., Rana, R. B., Ale, S., Poudel, I., \& Tamang, B. B. (2018). Use of agrobiodiversity and crop management practices for climate change adaptation in high hill agriculture of Nepal. Journal of Agriculture and Environment, 18, 6-14. https://doi.org/10.3126/aej.v18i0.19885

Hassen, M.B., Monaco, F., Facchi, A., Romani, M., Valè, \& G., Sali, G. 2017. Economic performance of traditional and modern rice varieties under different water management systems. Sustainability, 9(347). https://doi.org/10.3390/su9030347

IRRI. (n.d.). Nepal/International Rice Research Institute. Retrieved August 13, 2021, https://www.irri.org/where-we-work/countries/nepal

Joshi, B. K, Acharya, A. K., Gauchan, D., Bhatta, M. R., \& Upadhyay, M. P. (2017). Agrobiodiversity status and conservation options and methods. Conservation and Utilization of Agricultural Plant Genetic Resources in Nepal (BK Joshi, HB KC and AK Acharya, Eds). Proceedings of $2^{\text {nd }}$ National Workshop.

Joshi, B. K., Gorkhali, N. A., Pradhan, N., Ghimire, K. H., Gotame, T. P., KC, P., Mainali, R. P., Karkee, A., \& Paneru, R. B. (2020). Agrobiodiversity and its Conservation in Nepal. Journal of Nepal Agricultural Research Council, 6, 14-33. https://doi.org/10.3126/JNARC.V6I0.28111

Khanal, S., \& Dangol, D. (2016). (PDF) Assessment of landraces of rice and maize by four cell analysis at Sorabhag VDC Morang, Nepal. Himalayan Biodiversity, 4, 49-52.

Maclean, J.L., Dawe, D., Hardy, B., \& Hettel, G.P. (2002). Rice Almanac; International Rice Research Institute: Los Banos, Philippines.

MoAD. (2015). Rice varietal mapping in Nepal: implication for development and adoption. 90. http://doacrop.gov.np/

MOALD. (2021). Krishi Diary. Ministry of Agriculture and Livestock Development, 356.

MOFSC. (2014). Nepal Fifth National Report To Convention on Biological Diversity. In Government of Nepal Ministry 
of Forests and Soil Conservation: Vol. March (Issue March).

NEKSAP.(2013).Kaskidistrictfoodsecuritymap.NepalKhadhya Surakshya Anugaman Pranali (Nepal Food Security Monitoring System). https://neksap.org.np/allmaps/ kaski-district-food-security-map-apr-june-2013

Pfeiffer, L.M. (2003). Agricultural productivity growth in the Andean Community. American Journal of Agricultural Economics, 85(5), 1335-1341.

Rijal, D.K., Kadayat, K.B., Joshi, K.D., \& Sthapit, B.R. (1998). Inventory of Indigenous Rainfed and Aromatic Rice Landraces in Seti River Valley, Pokhara, Nepal. Local Initiatives for Biodiversity, Research and Development (LI-BIRD), 18, 37.

Sawaneh, M., Abd Latif, I., \& Abdulah, A.M. (2013). Total factor productivity of rice farming in selected Southeast Asian countries. In Proceeding of the International Conference on Social Science Research (4-5 June, 2013). Penang, MALAYSIA.
Shrestha, P.K. (2007). Mechanisms for Implementing Farmers' Rights on Plant Genetic Resources: Experiences from Nepal. Norwegian Ministry of Agriculture and Food (Issue September).

Shrestha, P., Sthapit, B. R., Poudel, D., \& Shrestha, P. K. (2015). Agricultural biodiversity in Nepal. May.

Sthapit, B., Lamers, H., \& Hegde, N. (2014). Four cell analysis: a participatory method to assess on-farm diversity status. Bioversity International, Nepal.

Wikipedia. (2020). Puranchaur - Wikipedia. https://en.wikipedia.org/wiki/Puranchaur 